\title{
Il diritto: un'invenzione dell'Occidente?
}

\section{Aldo Schiavone}

Storicamente, 2 (2006).

ISSN: 1825-411X. Art. no. 66. DOI: 10.12977/stor539

15 giugno 2006

Prof. Aldo Schiavone (Università degli Studi di Firenze)

Il diritto: un'invenzione dell'Occidente?

(conferenza)

[[figure]]figures/2006/Schiavone_1/Schiavone_1_2006_01.jpg[[/figure]] 